\title{
Perceptions, expectations, motivations: Evolution of Canadian views on the EU
}

\author{
NATALIA CHABAN1 \\ University of Canterbury, New Zealand \\ natalia.chaban@canterbury.ac.nz
}

\begin{abstract}
:
This article proposes a conceptual model that factors external and internal drivers behind external perceptions in IR and allows to trace their interaction across geographical distances argued by social identity theory (Moles and Rohmer, 1978) and evolution across historical distances defined by historical geography (Braudel, 1989). This article used the case of Canada's perceptions of the EU to demonstrate the model in action and trace the 'mental mapping' (Didelon-Loiseau and Grasland, 2014) of the EU's images through the perceptions of EU-Canada relation over time. Informed by the tripartite paradigm of the influential factors behind external perceptions of the EU: endogenous, exogenous and global (Tsuruoka, 2006; Chaban and Magdalina, 2014), the article offers a model that goes beyond this logic in an innovative way. It considers a geo-temporal matrix of vantage points that shape perceptions. To demonstrate the model in action, this article reviews existing research on perceptions of the EU in Canada focusing on the key works and their findings in this field over the last decade.
\end{abstract}

Key words: the EU, Canada, EU-Canada relations, evolution of perceptions, geo-temporal matrix of perceptions

\section{Introduction}

The story of Canada-EU relations may be told from different standpoints. For some scholars understanding of this relationship is ultimately about a story of strategic partnership, transatlantic alliance, as well as trade and investments. This article takes on board these considerations yet proposes a different way to think about this relationship - through a range of meanings attached to the relationship between the EU and Canada by actors inside Canada (local establishment, leading media and general public). The article focuses on an "interface between the political imagination of people, information flows, public reasoning and government policies" (Horbyk, 2017, p. 25) dissected through a prism of images and perceptions of the EU in Canada.

The paper goes beyond the description of perceptions and proposes a comprehensive model to explain perceptions of the relationship between the EU and a third country.

\footnotetext{
${ }^{1}$ The author would like express gratitude to the Jean Monnet Network on EU-Canada Relations: The EU and Canada in Dialogue for supporting research workshop "New Opportunities for the EU-Canada Strategic Partnership" at TU Darmstadt, Germany. Special thanks go to my co-editor and co-organiser of the workshop Professor Michèle Knodt of Technical University Darmstadt; all participants of the workshop for their useful feedback; Antoine Rayroux for his review during the workshop; and to the anonymous reviewer who helped to finalize this paper.
} 
The tripartite paradigm of the factors informs this research initially: endogenous (triggered by actions undertaken by the local, third country actors, without the EU's engagement), exogenous (triggered by the EU's actions without involvement of the third country) and global (triggered by actors outside of the EU's and the third country's control) (see Tsuruoka, 2006; Chaban and Magdalina, 2014). The paper adds to this model innovatively, by theorizing instances when interaction between the EU and a third country is a driver behind an image. The paper engages with the "mental map" theorization (Didelon-Loiseau and Grasland, 2014) and proposes to track images of EU-third country interactions along a set of geographical and historical 'distances'. The 'imaginary geographies', arranged in a particular pattern with the third country in the core, echo the logic of endogenous and exogenous factors, yet the article offers a model that goes beyond this logic. The model considers images of the EU in location-, region-, EU-specific and global 'spaces' through the filter of EU relations with Canada in the respective positions. This nuanced accounting for perceptions of the EU is complemented by a temporal dimension: the paper examines the impact of long-, medium- and short-term historical influences on perceptions.

The intersection of geographical and historical distances creates a matrix, and each 'cell' in this geo-temporal matrix becomes a different vantage point to understand how the EU is perceived in a third country. According to Chaban and Zhabotynska (2018), "Depending on the vantage point, the meaning assigned to each other or the perceived relationship between the two in the areas of political, economic, social or normative exchanges will vary". Perceptions are thus interpreted as a complex relational concept (see also Chaban and O'Loughlin, 2018). Considered in several recent studies of EU external perceptions (Chaban and Chaban, 2018; Chaban and Knodt, 2020), this model is applied here to trace and explain perceptions of the EU in Canada and their evolution over time. This is where the article contributes.

The article starts with detailing the theoretical model and follows with a brief description of the method. The study then analyses perceptions of the EU in Canada following the logic of the geo-temporal matrix. The study's findings reveal national $v s$. global trends and opportunities for the EU's leadership to advance its diplomacy towards Canada and revisit the EU's image and credibility in Canada. The concluding summary maps the evolving images of the EU in Canada and elaborates what they may mean for Canada-EU relations. The conclusion discusses how the awareness of the evolution of images may point to the areas where the EU could exercise the most impact in its relations with Canada.

\section{Theoretical framework}

As Fisher (1997, p. 4) notes, "international relations evolve around interplay of images" (see also Movahedi, 1985; Herrmann et al., 1997). The latter emerge from subjective perception and reconstruction of the "objective international reality" (Movahedi, 1985, p. 3). Relevant literature argues the interplay of factors that are critical to reconstruct an image of that reality: (1) exogenous (EU), (2) endogenous (third country), and (3) global factors (Tsuruoka, 2006; Chaban and Magdalina, 2014). In the core of this model is differentiation between internal and external factors that impact images. For some time, relevant literature on perceptions has focused on the EU-specific actions as a driver behind perceptions almost exclusively (e.g. the impact of EU enlargement, failed Constitutional Treaty, Eurozone debt crisis or Brexit, among many examples). Tsuruoka was among first to attract attention that images of the EU are a complex 
construct that is shaped not only by 'what the EU does or says' irrespective of the third country actions (exogenous factors, according to Tsuruoka). For example, elections of a local governement may trigger a foreign policy with a particular vision of Europe/the EU. As such, what the third country actors do or say - independently from the EU may also influence the image of the EU (the so-called endogenous factors). Chaban and Magdalina (2014) empirically tested and statistically proved another factor - global impacts. In this case, global scale events and actors on the global stage influence EU images: "EU perceptions will inevitably relate to understandings of global trends, geopolitical contexts and economic interdependencies" (Chaban et al., 2018b, p. 13). Importantly, neither the third country's nor the EU's actions are the main triggers of EU images in this case. For example, UN climate conventions influence how the EU is imagined around the world.

The original model by Tsuruoka (2006), and its later elaboration by Chaban and Magdalina (2014), stresses the actor dimension and is not clear about scenarios when the EU and a third country are interacting. When interactions are in view, is it endogenous or exogenous influence? Keeping the notion of interaction in mind, this paper proposes a new model that outlines a set of vantage points to understand perceptions of the EU when interactions are involved. In totality, these vantage points build a dynamic "mental map" (Didelon-Loiseau and Grasland, 2014) for charting the images of the EU in a third country (Table 1).

The first element of the model deals with "imaginary geographies" of the EU-third country interactions. The imaginary geographies are not random. They are argued to be arranged in concentric circles, with the Self at the core of it. This vision is informed by the social identity theory of "men's shell” (Moles and Rohmer, 1978). Cited by Didelon-Loiseau and Grasland in their cognitive mapping model, this theory argues a "series of circles organized around the individual that define the level of knowledge of different places. In this theory, closer spaces are the best known" (2014, p. 46). Imaginary geographical distances are expected to influence the images of the EU depending on their 'distance position': third country (Canada)-, region-, the EU-, and finally world-focused.

Didelon-Loiseau and Grasland (2014) also attract attention to the importance of temporal distances. Guided by Braudel's vision on historical distances in terms of long, medium- and short-term temporalities (Braudel, 1989), studies of perceptions of the EU are increasingly engaging with historical dimension (e.g. Chaban and Chaban, 2018). The incorporation of the temporal dimension allows tracking the evolution of images of the EU and EU-Canada interactions in Canada and argues a historical position to be yet another key driver to understand images of the EU when it interacts with the third countries. Intersections between geographical and historical distances allow this article to argue a relational character of EU perceptions, especially in the case of EU-Canada interactions. 
Table 1: Analytical geo-temporal matrix

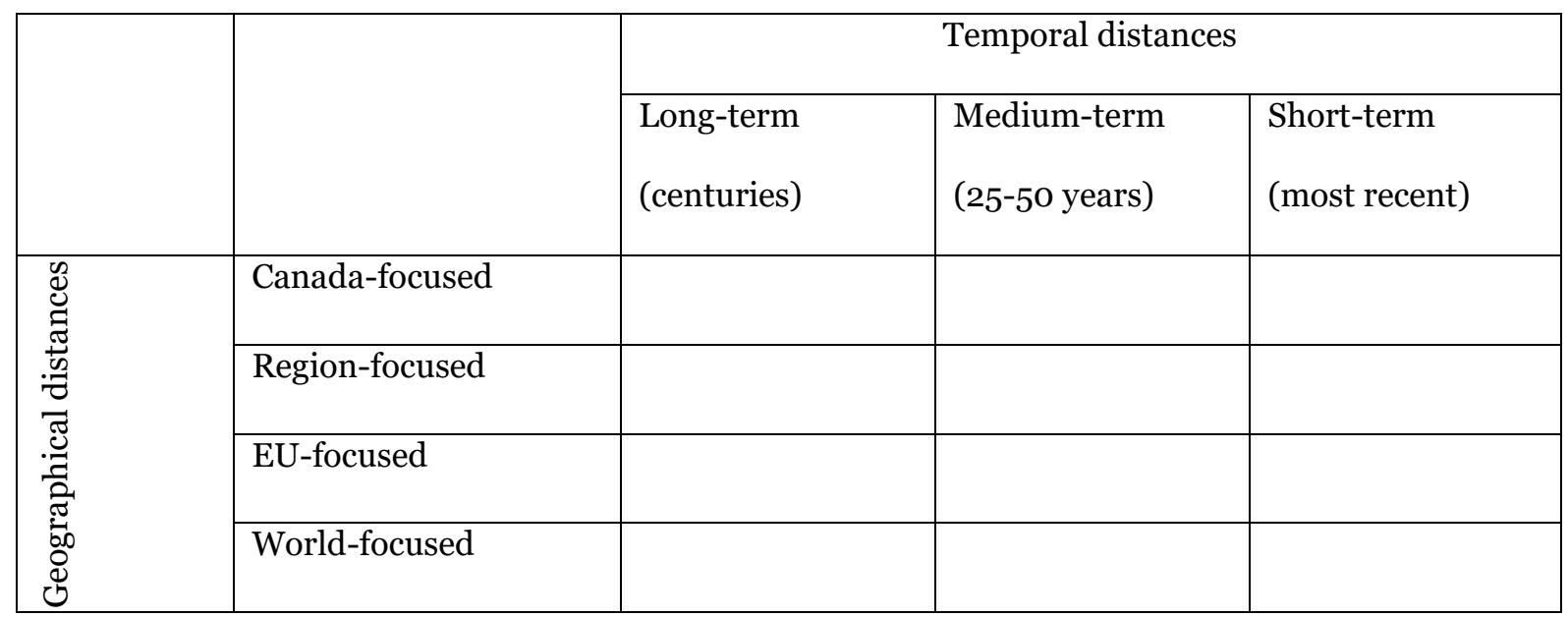

\section{Method}

To demonstrate the model in action, this article reviews existing research on perceptions of the EU in Canada undertaken over time. Keeping in mind a relatively small pool of studies of the EU perceptions in Canada, this article consults the key works in this field over the last decade: Croci and Tossutti (2007a,b), Gänzle and Retzlaff (2008), Retzlaff and Gänzle (2008), Rayroux (2018), Chaban, Kelly and Rayroux (2018), and the latest research in the field (in the context of Brexit) by Hurrelmann (2018, 2020). It also engages with the primary datasets from the 2015 research "Analysis of EU policies abroad and EU global perceptions" in the EU's ten strategic partners (a project commissioned by the EEAS and run by a consortium of three research centres (PPMI/NCRE/NFG, 2015)). Canada was one of the ten countries studied in it. The article also consults Eurobarometer survey "Future of Europe - Views from outside the EU" conducted in 2017 (run in 11 non-EU countries, including Canada) (European Commission, 2017). Finally, the findings of the Canadacentered IPSOS public opinion survey was also considered (IPSOS, 2016).

\section{Findings}

\section{Canada-focused}

With the EU being a relatively young historical phenomenon, the long-term historical influences (over centuries) have to deal with the notion of 'Europe'. Canada's history features major influences by the two European colonial powers - the UK and France. The consequences of their expansion overseas have been, and will be, intrinsically woven into the identity narratives of Canada - be they cultural, political, linguistic, administrative or normative (see Chaban et al., 2018a). Canada of the $21^{\text {st }}$ century is a country critically revisiting the European 'chapter' in its history. It pro-actively acknowledges the indigenous legacy and supports its First Nations as co-contributor and co-shapers of the national identity and narratives. Arguably, the vision of Europe in this intersection of geographical and historical distances is ambivalent. It is difficult to deny Europe's foundational influences on the present-day Canadian society. Yet, the reflection on the role of European powers in this context comes in through a critical assessment and re-evaluation. 
Adding to the ambivalence is another century-old influence coming from Europe - the legacy of the two World Wars. Both wars were of 'European origin', yet Canada had stepped in and sacrificed its people and resources. One key outcome of these historical decisions was a growing identity of an independent Canada - a sense of nationhood (Retzlaff and Gänzle, 2007, p. 72) and a self-vision of a "middle power" standing on its own in the world (Haws, 1984; Cooper et al., 1993; Nossal, 2010; see also Zyla, 2019, in this Special Issue). This may mean a more positive self-reflection in relation to Europe, yet the trauma induced by the two wars scars the image of the 'old continent'.

Keeping in mind Canada's sacrifices to 'Europe of wars', it would be natural to expect that 'Europe of peace' emerging after WWII would be supported by Canada enthusiastically. Yet, the early mid-term visions on integrating Europe were lukewarm, oscillating between indifferent and negative (Croci and Tossutti, 2007, p. 288). Canada had an uneasy feeling towards the integration initiatives (specifically the UK's accession) fretting trade threats. Nevertheless, the initially suspicious attitude did not preclude Canada from obtaining the diplomatic accreditation to Brussels as early as 1960 (Rayroux, 2018).

Parallel to the progress of the European integration project, Canada went through its own political evolutions in the last half a century. A Western liberal democracy, Canada draws its leadership from two leading parties - Liberals and Conservatives. Since the inception of the European integration project, these parties took turns in leading the country while displaying different patterns in attitudes and visions of foreign policy, with Conservative leaders typically prioritizing relations with the US (for comprehensive analysis of the perceptions of the European integration among Canadian establishment, see Hurrelmann, 2018, 2020). It is important to stress that the distinction between Conservatives and Liberals in Canada is not as profound as it is in the US between the Republican and Democratic parties. Overall, there is still quite a strong strain of liberal internationalism that runs within both the main parties, and Conservative governments have also prioritized building relationships with other actors beyond the US, especially in the Americas, but also China. As such, visions of the EU as a priority of Canadian foreign policy may correlate with the visions of the party leading the government to some extent, and are seemingly in flux over time.

In the mid-term flow (the 1980 s and early 1990s), the "lack of enthusiasm from the business sector continued and tensions emerged following a series of trade disputes" (Rayroux, 2018, p. 58). This period featured some aggravations in EU-Canada relations which have impacted the perceptions (see Bernard-Meunier, 2006; Croci and Tossutti, 2007ab; Hurrelmann, 2018; Rayroux, 2018; Verdun, 2019 (in this Special Issue)). Among others, the aggravations included the vestiges of the EU's Common Agricultural Policy (CAP), the EU's ban on seal products and fur sales, and the conflicts over fisheries in the North Atlantic. They were compounded by multilateral-level clashes (e.g. Canada's opposition to the EU's bid for permanent observer status in the Arctic Council in 2009 or Canada's pulling out from the Kyoto agreement in 2011). Yet, the short-term history saw a revivial of the EU-Canada cooperation in the multilateral climate realm (see Bendiek and Schenuit, 2019, in this Special Issue).

The short-term frame is marked by the general public perceptions of the EU as an industrial power. The trading power of the EU is the most commonly mentioned as the main asset of the EU by respondents of the Eurobarometer survey (2017). Perhaps unsurprisingly then, this time period is also marked by in two main advances in the EU- 
Canada relations: the launch of the Comprehensive Economic and Trade Agreement (CETA) (advocated by Canada) and a new Canada-EU Strategic Partnership Agreement (SPA) (advocated by the EU) (see Knodt and Chaban (2019) and Verdun (2019) in this Special Issue). The final ratification of the CETA has not yet taken place, but it is provisionally in force. The SPA - a more politically oriented agreement - came into force in 2016. For Verdun (2009, p.20, in this Special Issue), "the eventual combination of the CETA and the SPA became the most comprehensive agreement between the EU and Canada to date, including many different dimensions (political, economic, strategic, security, judicial, environmental and social)" (see also Bendiek et al., 2018). Hurrelmann $(2018,2020)$ argued that this positive course in perceptions has been supported by election (in 2015) of the Liberal Party under Justin Trudeau. Under the Trudeau's administration (Trudeau was re-elected in 2019), the EU and Canada have managed to alleviate the above-mentioned conflicts. As such, the ambivalent image of the EU remains on the short-term historical plane, yet a positive tenor seems to lead in the perceptions of the EU in Canada in the most recent years.

Research by Rayroux (2018) supports this sentiment and reports more recent positive views shared by Canadian elites' as well as within the general public. In the former case, the interviews with business and political elites demonstrated that CETA is seen as the key central issue for EU-Canada relations. It strengthened the principal image of the EU as a trading actor able to speak with a unified voice (in this case, in bilateral or multilateral trade negotiations). Finally, Canadian elites saw CETA as a less contentious trade agreement than NAFTA or TPP (Trans-Pacific Partnership). Rayroux cited two reasons of the caution about these two trading agreements: "Canadians feared the dominant power of the US or the risk of lowered standards by Mexico or Asian countries" (2018, p. 63). In contrast, "The brand 'Europe' ... is very strong here" (a Canadian think tank cited by Rayroux, 2018, p. 63). The EEAScommissioned public opinion poll in Canada in 2015 found that trade was the area "where relations with Canada were seen by the public as being the most prominent. 58.2 per cent of the respondents 'agreed' or 'strongly agreed' with the statement that the EU was an important trade partner for Canada, and 48.8 per cent that the EU was an important investor in Canada" (Rayroux, 2018, p. 63). In the Canadian prestigious popular media "trade was the second most visible economic issue. Overall, 49 articles mentioned EU trade policy, 37 of which addressed the issue of CETA. Because of CETA, trade was also the topic that had the most local resonance in the Canadian print media: 43 per cent of the articles with a local resonance (93 articles in total) concerned CETA" (Rayroux, 2018, p. 63).

Finally, Canada's long-, mid- and short-term perceptions of Europe/the EU, are influenced by the logic of provinces: the "federal and regional nature of Canada influences images and perceptions of the EU, because of specific geographic, historic, economic or cultural features of the country's various regions" (Rayroux, 2018, p. 71). According to Rayroux' study of elite opinion in Canada, Quebec is being seen as "having a strong appetite for European - rather than just French - culture, followed by Ontario, while Central or Western provinces were seen as more distant and less concerned" (2018, p. 71). Rayroux' research also found that perceptions of the CETA were province-specific depending on the provinces' dominant economic sectors. 


\section{Region-focused}

A typical definition of 'region' focuses on the immediate geography, i.e. perceptions of the EU through the lense of Canada's relations with the US. However, the review of existing literature on Canada's perceptions on the EU points to two other 'imaginary regions' in the mental mapping of Canada, namely NATO and the Commonwealth. Different visions of the EU and Canada-EU relations emerge in the respective 'imaginary' regions.

\section{Region 1 "The North America"}

According to Croci and Tossutti (2007, p. 289), “...Canada's attitudes to the EU are best understood when seen against the background of its evolving relations with the USA". Canada cannot 'escape' its geography and the US as its neighbour. Unsurprisingly, with the US being a regional hegemon, Canada's economic dependency on the US is much stronger than on the EU (see Verdun (2019) and Zyla (2019) in this Special Issue). In the long-term frame, the extended negotiations with the US on the Canadian borders shaped the vision 'what is us, Canada' vs. 'what is them, the US' feeding into the nation-building discourse. The negotiations, ongoing since the $18^{\text {th }}$ century and lasting to the start of the $20^{\text {th }}$ century (with some remaining disputed territories in the $21^{\text {st }}$ century) list a number of treaties struck between the US and a European actor, the UK. The latter aimed to secure as much territory for its North American British colonies as possible (arguably, adding to a positive perception of Europe, through the UK lense). Moreover, many of these treaties took place in Europe, traditionally seen as a location with a diplomatic cache and established authority in negotiations.

In the mid-term timeframe, Canada's relations with the US is one of the reasons why "the Canadian government showed some unease with the process of European integration from it very beginnings" (Croci and Tossutti, 2007, p. 289). According to these scholars, Canada's preference for the North-Atlantic-wide free trade using the NATO frameworks clashed with the European Common Market limited to some Europeans members only. The fractures in Alliance meant to Canada "the increase and entrenchment of the growing economic dependence on the US market" (Croci and Tossutti, 2007, p. 289). As mentioned above, Conservative leaders of Canada have a tendency to favour closer relations with the US. The mid-term timeframe features many examples of it (e.g. North America-focused FTAs of CUSFTA or NAFTA initiated by the Conservative governments) (Hurrelmann, 2018, 2020). In another example, Canada under the Conservative leadership stepped out of Kyoto protocol (see Bendiek and Schuneit, 2019, p.51, in this Special Issue), mirroring the US' stance on climate multilateralism. Having said that, the EU is often seen as a needed counterbalance to Canada's heavy orientation towards the US in its foreign and trading policies (Retzlaff and Gänzle, 2008). Still, Canada's economic dependency on the US and the breadth and depth of the myriads of US-Canada connections cannot be underestimated. The US has been and will remain in the main focus of the Canadian foreign policy irrespective of political leanings of its governments.

The post-Cold War unilateral world order under the US leadership and the current status of the US as a global 'heavy hitter' have left an imprint on Canada's psyche always 'in the shadow' of the US, including in the relations with the EU. Rayroux (2018, p. 67) brings an example from the 2016 EU Global Strategy where "Canada is never 
mentioned as a standalone strategic partner, but always in conjunction with the US, both being part of what the EU describes as 'the Atlantic' - one of the EU's important cooperative regional orders". As such, the EU is seen as a somewhat ignorant, if not inattentive partner for Canada, not being able to remember Canada or appreciate its difference with the US. Here the self-images of Canada vis-à-vis the US and Europe are important to mention. Croci and Tossutti (2007, p. 309) mentioned that "Canadians ... seem to believe that Canadian and European values and interest are more akin than those between Canada and the USA, and Europe and the USA". Rayroux (2018, p. 67) echoes this view citing Adams (2003) and Jones \& Kilgour (2007): "Canadian and US populations increasingly diverge in terms of cultural values, Canada becoming more postmodern than the US".

In the short-time frame, Canada's neighbour ended with Trump's administration with its uneasy position towards Brussels. Trump's skepticism towards the project of European integration has not rubbed off the current Canadian administration led by Trudeau for the second term. Canada's present-day relations with the EU are mutually cordial and advanced (with CETA and SPA being the most telling examples). The two agreements with the EU can be interpreted as Canada's responses to the uncertainty facing global multilateralism (see Rayroux, 2019, in this Special Issue) vis-à-vis the US' retreat from the rule-based international order.

\section{Region 2: "Transatlantic // NATO"}

The 'transatlantic' imaginary region links Canada, the US and the EU/Europe in the context of security. According to Hurrelmann (2018, 2020), the EU is not seen in Canada as a leading global security actor. Rayroux echoes this observation - he sums up the main findings of the 2015 survey noting that "the Canadian public saw the EU's performance lagging behind the US and the UN in terms of security such as peacekeeping operations, military operations or the fight against terrorism" (2018, p. 68). Nevertheless, EU states are seen as important and valuable security partners to Canada when they are members in NATO. Significantly, Canada has supported NATO's international multilateral framework enthusiastically from the onset of this organization, and it remains a pro-active and committed member (for comprehensive review of Canada-NATO relations and relevant literature, see Leuprecht and Hamilton, 2019, in this Special Issue). Perhaps unsurprisingly, Canada's self-images in this region are of a capable and valued actor.

Positioned vis-à-vis Canada's self-images in the mid- and short-term timeframe, images of the EU ranged from neutral (a sui generis actor who is not a major security actor in the world) to positive (specifically, through EU member states who are NATO members). This analysis adds that the latest NATO Summit in London in December 2019 demonstrated closeness between the Canadian PM Trudeau and its European counterparts. This was observed even on a benign level - in an infamous episode at the summit's opening reception, Justin Trudeau, appeared to be joking about Donald Trump with the UK's PM Boris Johnson, French President Emmanuel Macron, Dutch PM Mark Rutte and Princess Anne, triggering President Trump's furious reaction (Wintour and Manson, 2019).

\section{Imaginary Region 3: "Commonwealth"}

In addition, Canada sees itself as a part of a different geopolitical historical region - a global conglomerate of former colonies of the UK, the Commonwealth. Most works in 
the field of perceptions of the EU in Canada, not that the UK has had a special impact on the images of Europe and the EU, as well as Canada's relations with Europe. In the long-term timeframe, Canada was titled - and saw itself - as "British North America" (or as Retzlaff and Gänzle put it, "Canada was viewed and treated as Great Britain's little North American cousin" (2007, p. 72)). A particular self-image of an important and privileged member of the Commonwealth followed this special status. Yet, these special ties were tested in the 1960s-70s, when the UK decided to join the EEC (see also Croci and Tossutti, 2007). This mid-term development meant a stop to Canada's preferential trading relations with the UK and this was seen in a negative way. Consider that in 1948, 22 per cent of Canadian experts went to the UK $v s$. early 1970s when only 7 per cent went to the UK (with 6 per cent more going to the six countries forming the EC) (Croci and Tossutti, 2007, pp. 289-290). Yet, a prolonged period of the UK's accession to the EU presented Canada with an opportunity to revisit the logic and perceived priority of the special trading links with the UK. Canada had recognized that 'putting all its eggs in one basket' trade-wise is a risky strategy (that also included trade with the US) and responded with its vision of the "third option" which meant a broad and proactive diversification of its trade in general (see Verdun (2019, p.53) in this Special Issue, citing Mace and Hervouet, 1989).

Despite the broadening of the group of its leading trading partners, Canada had continued to see the UK as a close and natural contact for Canada within the Union in trading and security terms. During Britain's 47-year tenure in the EU, the UK has been and has been seen as the leading trading partner for Canada within the EU (Hurrelmann 2018, 2020). It was seen and used as a 'spring board' for Canadian businesses and investments to reach continental Europe. The UK, an ardent supporter of the free trade, had an image of an EU member states who can relate to the value Canada assigns to free trade. According to Hurrelmann $(2018,2020)$, in security field, the UK is seen a valuable ally within NATO. Cultural and intellectual ties between Canada and the UK have been unwaveringly strong. Moreover, the UK has retained a leading position in being a source and a supplier of information about the European project. The English-language news media in Canada has traditionally used the UK sources to report the EU (in addition to the US sources) (Chaban et al., 2018a; Gänzle and Retzlaff, 2008; Retzlaff and Gänzle, 2008). The French news sources are used heavily only by the Quebec media (Rayroux, 2018).

The short-term event of Brexit presented Canada with a somewhat unexpected situation. According to Hurrelmann's comprehensive analysis of perceptions of the EU in Canada in the context of Brexit (2018, 2020), Brexit has triggered certain politicization of views inside the Canadian establishment. Former Conservative leader Andrew Scheer, stated his support of Brexit - first in a 2016 op-ed in the National Post prior to the referendum (Sheer, 2016) and then later in a series of statements in 2018 (Rabson, 2018). This is a new trend in Canada's perceptions of the EU, and something to be explored in the future, when Brexit is finalized. Importantly, it remains to be seen how many Conservatives subscribed to this view. The general public opinion also remains unclear. Hurrelmann (2018, 2020) cites the 2016 Ipsos Mori public opinion survey: when asked if Brexit was the right or the wrong decision for Canada, 61 per cent of respondents opted for the "don't know" reply. 


\section{EU-focused}

On a long-term plane, Europe - as a wider concept with centuries of cultural and civilizational cache - remains a powerful reference for the Canadian society. A 'New World' country, Canada appreciates innumerable connecting links to the 'old' continent, with the UK and France being the two main historical impacts. Keeping in mind these historical links, it is interesting to see the results of the 2015 study of perceptions of the EU vis-à-vis Europe (PPMI/NCRE/NFG, 2015). It showed that the most visible themes assigned to the notion of 'Europe' by the Canadian reputable press were economy followed by social and cultural issues. These themes were mentioned more often than politics, unlike in the articles covering the EU. The same study found that such themes as research, science and technology, as well as energy were covered more often in article mentioning Europe than in articles mentioning the EU. According to the report, these media profiles correlate with the public opinion traced in the nation-scale survey: "in Canada, respondents associated areas as economy and politics first and foremost with the EU, whereas they more often linked culture, sports and science to Europe" (PPMI/NCRE/NFG, 2015, online). Europe's coverage in the leading press was found to be more balanced and also more neutral in evaluations than the coverages of the EU: some 4 per cent of all articles mentioning Europe were positive, another 4 per cent were negative, whereas the majority was neutral (PPMI/NCRE/NFG, 2015, online). In contrast, the EU was consistently framed more negatively than Europe (22 per cent of the total coverage), but also had more articles with positive evaluations (11 per cent).

The mid-term frame, which coincides with the beginning of the European integration process, sees a roller-coaster of attitudes towards the EU and a range of perceptions. While the initial moves by six European states to create the ECSC were perceived with relative indifference in Canada (see Croci and Tossutti, 2007), their decision to expand by accepting the UK into the 'club' triggered a negative reaction in Canada. Yet, a pragmatic sentiment has overcome the initial panic, and Canada has initiated closer relations with the EC as early as only one year after the Treaty of Rome was signed in 1957 (Retzlaff and Gänzle, 2008, p. 72).

As mentioned above, in the 1970s-90s, a number of the EU's policies - mainly in the realm of trade - triggered negative images of the European project in Canada. Among the policies seen to hurt Canada are the CAP, which Canada has opposed openly and vocally (Croci and Tossutti, 2007a), as well as the conflicts over fisheries in the North Atlantic or the EU's ban on fur sales (Rayroux, 2018). These thorny interactions have impacted perceptions as noted by Woods and Verdun (2010, pp. 12-13) in their review of literature on EU-Canada relations published between 1982 and 2010. Citing Croci and Tossutti (2007b) and Bernard-Meunier (2006), they noted that the relevant publications "suggest that Canadians believe that Europeans overuse trade distorting measures (e.g. agricultural subsidies), engage in overfishing in international waters, have too much bureaucracy and overly rigid labour markets, and should get over their dislike for genetically modified foods, seal products and furs".

Despite these challenges, Canada pursued a dialogue with the EU in the trade field: Framework Agreement for Commercial and Economic Cooperation was signed in 1976. It was the first formal cooperation agreement that the EC had ever made with an industrialized country (Verdun, 2019, in this Special Issue). Importantly, the preamble to the Framework Agreement "emphasises the role of the common heritage, special 
affinity and shared aspirations which unite Canada and the countries of the European Communities" (Agreement 1976 cited by Retzlaff and Gänzle, 2008). This formulation reveals a neutral-to-positive view of the EU in the mid-term flow while linking to the long-term cultural legacies. In addition to the economy-related agreement of 1976, the EU struck in 1990 a Declaration on Transatlantic Relations with Canada. Its framework aimed to increase and diversify EU-Canada contacts and came with a mechanism of regular meetings at the Summit and Ministerial level (Retzlaff and Gänzle, 2008).

The beginning of the $21^{\text {st }}$ century came with a number of big moves in the EU - the introduction of the Schengen zone, the Euro currency and the 'Big Bang' Enlargement. These moves were framed by the Canadian media from a variety of standpoints. Relevant research found "particular representations of the EU according to [newspapers] own ideological affiliations" - Canadian press that side with conservative and pro-American stances tend to report EU-related issues in more Euro-sceptic ways (Retzlaff and Gänzle 2007, p. 86).

On the short-term pane, the crises in the EU have left an increasingly negative imprint on the images of the Union in Canada. Research undertaken in 2015 - the year that featured a dramatic start to the irregular migration crisis and the EU's failure to cope with it, a UK PM's decision to hold referendum on the UK's exit from the EU, and yet another peak in the Eurozone crisis in Greece - showed that media coverage of the EU in Canada prioritized these dramatic topics stressing negativity in the portrayals of the EU more than positivity (PPMI/NCRE/NFG, 2015; Rayroux, 2018). Yet, most of the coverage was still of neutral tenor (63 per cent). Perhaps then unsurprisingly, public opinion measured in Canada in 2015 remained relatively positive: 38.7 per cent of the respondents felt 'very' or 'somewhat positive' about the EU, while just 10.5 per cent felt 'very' or 'somewhat negatively' (Rayroux, 2018). The top adjectives chosen by the respondents of this survey to describe the EU were rather positive too - united, peaceful, trustworthy and efficient. In the 2017 Eurobarometer survey "Future of Europe - Views from outside the EU", 79 per cent of respondents reported positive view on the EU, with 14 per cent of respondents reported their view of the EU as "very positive" (European Commission, 2017). Interviewed in 2015 elites also shared a generally positive view on the EU.

Nevertheless, well informed about and socialised with Europe Canadian decisionmakers shared certain negative perceptions. They "pointed to a series of structural weaknesses such as the inconsistencies between the EU and the member state level and the EU's bureaucratic regulatory character" and "expressed frustration at the tensions between the Commission and the member states, which created numerous confusions among Canadian businesspeople" (Rayroux, 2018, p. 69). In the latest period, Brexit has introduced more negativity into the public opinion. In his comprehensive study of EU perceptions in the context of Brexit in Canada, Hurrelmann $(2018,2020)$ cites Ipsos Mori survey (2016) that found 44 per cent of respondents in Canada seeing Brexit as a wrong decision for the UK and 47 per cent fo the EU. Morover, this survey also registered perceptions of harmful impact of Brexit on the EU's and the UK's economy and global influence. Yet, a survey conducted only a year later - Eurobarometer survey (European Commission, 2017) - reported that the majority of Canadian respondents (66 per cent) totally agreed or tended to agree that the EU is a place of stability in the troubled world. 


\section{World-focused}

Canada sees itself as 'middle power' of the world (see Zyla (2019) in this Special Issue; Haws, 1984; Cooper et al. 1993; Nossal, 2010). In a brief summary here, this particular self-vision is an outcome of the two World Wars (both of European origin). The legacy of the 'European wars' - and Canada's contribution to them - is thus a long-term factor on a global scale. According to Zyla (2019, p. 75, in this Special Issue), formulated in the aftermath of the WWII, "the image of Canada as a middle power and a transatlantic bridgebuilder helped foreign policy officials in Ottawa to help Canadians to understand their country's relative power capabilities, and how it could contribute to international politics".

Mid-term timeframe had built on the images of the "middle power" and brought a vision of Canada and Europe as the drivers and supporters of the multilateral liberal world. In this historical period, Canada could relate to the EU as it saw the EU as a principled multilateral player (and, importantly for Canada, more so than the US, reinforcing the image of the EU as a "counterweight" to the US discussed above) (Retzlaff and Gänzle, 2008, pp. 72-73). Arguably, neutral-to-positive images of the EU lead in this historical period on this level.

The short-term developments come with two major impacts that Canada cannot overlook or ignore - the election of Trump as the President of the US and Brexit. Commentators around the world argue that these two events have global repercussions and signal a serious threat to the multilateral liberal world order. Canada's perceptions of the EU27 as a vociferous advocate of multilateralism come with potential for positive evaluations. Canada and the EU are now sharing self-visions of being among main proponents of maintaining and reasserting the rules-based order, and their relations can be critical for the changing world. This argument is further supported by the reference of EU-Canada summit in July 2019 which stressed among its key points the "shared commitment" uphold by the EU and Canada to strengthen the "rules-based international order" (European Council, 2019). The public opinion profiled a positive image in this context. In the 2015 survey (PPMI/NCRE/NFG, 2015), respondents, reflecting on the desirability and likelihood of EU international leadership, described as 'very' or 'somewhat' desirable global leaders by 58.7 per cent of the respondents vs. 6 per cent who saw it as 'very' the EU or 'somewhat' undesirable with 53.1 per cent regarding this as 'very' or 'somewhat' likely vs. 8.3 per cent unlikely.

\section{Conclusions}

This article proposes a conceptual model that factors external and internal drivers behind external perceptions in IR and allows to trace their interaction across geographical distances argued by social identity theory (Moles and Rohmer, 1978) and evolution across historical distances defined by historical geography (Braudel, 1989). This article used the case of Canada's perceptions of the EU to demonstrate the model in action and trace the 'mental mapping' (Didelon-Loiseau and Grasland, 2014) of the EU's images through the perceptions of EU-Canada relation over time (Table 2). 
Table 2: Geo-temporal Matrix: Results

\begin{tabular}{|c|c|c|c|c|}
\hline & & \multicolumn{3}{|c|}{ Temporal distances } \\
\hline & & $\begin{array}{l}\text { Long-term } \\
\text { (centuries) }\end{array}$ & $\begin{array}{c}\text { Medium-term } \\
(25-50 \text { years })\end{array}$ & $\begin{array}{c}\text { Short-term } \\
\text { (most recent) }\end{array}$ \\
\hline \multirow{4}{*}{ 包 } & $\begin{array}{l}\text { Canada- } \\
\text { focused }\end{array}$ & $\begin{array}{l}\text { Ambivalent ('Europe' in } \\
\text { view, the legacy of } \\
\text { colonial past and WWI } \\
\text { and WWII) }\end{array}$ & $\begin{array}{l}\text { Initial indifference, } \\
\text { followed by suspicion } \\
\text { and negativity (due to } \\
\text { perceived trade threats) } \\
\text { Fluctuating depending on } \\
\text { the government } \\
\text { Dominated by a } \\
\text { pragmatic approach }\end{array}$ & $\begin{array}{l}\text { Neutral-to-positive (CETA, } \\
\text { SPA) } \\
\text { Positive image of an } \\
\text { important trading partner } \\
\text { (among general public and } \\
\text { elites) }\end{array}$ \\
\hline & $\begin{array}{l}\text { Region- } \\
\text { focused }\end{array}$ & $\begin{array}{l}\text { Neutral-to-positive } \\
\text { Europe as a location with } \\
\text { diplomatic expertise } \\
\text { where negotiations with } \\
\text { the US about the borders } \\
\text { take place } \\
\text { In } 18^{\text {th }}-20^{\text {th }} \text { centuries, the } \\
\text { UK is using its diplomatic } \\
\text { skills to secure territories } \\
\text { for 'British North } \\
\text { America' in negotiations } \\
\text { with the US }\end{array}$ & $\begin{array}{l}\text { Ambivalent: } \\
\text { Uneasy (European } \\
\text { Common Market splits } \\
\text { NATO members who could } \\
\text { participate in the North } \\
\text { Atlantic-wide trade area } \\
\text { and increases Canadas's } \\
\text { economic dependency on } \\
\text { the US) } \\
\text { Positive (EEC/EC/EU as a } \\
\text { counterbalance to the US; } \\
\text { actor with affinity in culture } \\
\text { and values) } \\
\text { Neutral-to-positive in } \\
\text { the context of the "NATO } \\
\text { region" }\end{array}$ & $\begin{array}{l}\text { Neutral-to-positive } \\
\text { (Canada and European } \\
\text { members continues to see eye- } \\
\text { to-eye on the NATO's } \\
\text { importance, while the US } \\
\text { questions the alliance) } \\
\text { Potentially } \\
\text { divided/unclear in the } \\
\text { context of Commonwealth, } \\
\text { due to Brexit }\end{array}$ \\
\hline & $\begin{array}{l}\text { EU- } \\
\text { focused }\end{array}$ & $\begin{array}{l}\text { Neutral (Europe seen } \\
\text { mostly in such issue-areas } \\
\text { as economy, social and } \\
\text { cultural affairs, research, } \\
\text { science and technology, } \\
\text { energy) }\end{array}$ & $\begin{array}{l}\text { Negative first (at the } \\
\text { inception of the European } \\
\text { project when the UK was } \\
\text { about to join the EEC) } \\
\text { Negative (in response to } \\
\text { obstacles imposed by the } \\
\text { EU in the area of trade } \\
\text { policies) } \\
\text { Neutral at the start of } 21^{\text {st }} \\
\text { century, when many EU } \\
\text { initiatives took place (the } \\
\text { Euro, Schengen, } \\
\text { Enlargement) }\end{array}$ & $\begin{array}{l}\text { Negative in reaction to EU } \\
\text { crises (e.g. migration crisis, } \\
\text { Brexit) (NB: not necessarily } \\
\text { negative about the EU as an } \\
\text { institution, but instead about } \\
\text { the things that are happening } \\
\text { to the EU) } \\
\text { Media framing is more } \\
\text { negative, while public } \\
\text { perceptions are more } \\
\text { positive. Elites are } \\
\text { ambivalent. }\end{array}$ \\
\hline & $\begin{array}{l}\text { World- } \\
\text { focused }\end{array}$ & $\begin{array}{l}\text { Neutral-to-negative } \\
\text { (legacy of WWI and } \\
\text { WWII, but it leads to the } \\
\text { self-vision of "middle } \\
\text { power") }\end{array}$ & $\begin{array}{l}\text { Neutral-to-positive } \\
\text { (advocate and supporter of } \\
\text { multilateralism, affinity } \\
\text { with Canada) }\end{array}$ & $\begin{array}{l}\text { Positive (EU27 as an firm } \\
\text { advocate for multilateralism } \\
\text { and rules-based order in the } \\
\text { world of Trump and Brexit; } \\
\text { desirable global leader) }\end{array}$ \\
\hline
\end{tabular}


The Canada-focused perceptions reveal that images of the EU and EU-Canada relations are ambivalent throughout history, albeit for different reasons in every historical intersection. This inherent long-lasting ambivalence (leaning to positive images most recently) must be factored into the EU's future dialogue with Canada. Some of this ambivalence is linked to the cyclical events in the Canada's political life the attitude and images of Europe/the EU may fluctuate according to the party that is elected to govern the country. While pragmatic and benefit-oriented images of the EU seem to emerge over time, the EU should account for its nuanced images when dealing with Canada across political continuum. This is even more important keeping in mind potential polarization of the Canadian political life in the mid-term future (short-term polarisation was argued by Hurrelmann, 2018, 2020). While current government supports a multilateral world-view, Canada's major economic dependency on the US will remain. Despite some short-term crises in the US-Canada relations, the links between two countries continue to be multiple and deep. These trends may potentially mobilise a political majority with a stance aligning more with the US and moving away from multilateralism. Canada domestic politics will remain a key factor for the future Canada-EU relations and images of the EU.

The Canada-specific perceptions had an additional geographical dimension to them. They were province-specific reflecting Canada's federal structure and country's regions difference in terms of geographical peculiarities, socio-economic profiles and historiccultural features (see also Verdun, 2019, in this Special Issue). The province-specific perceptions differed in their reflections on cultural connections as well as economic ties with the EU. Future studies of EU perceptions in Canada should factor differences across political continuum as well as provinces to inform a more effective dialogue of the EU with this democratic multilevel nation.

The logic of regions - either 'geographical/North American neighbourhood', 'security transatlantic' or 'geopolitical historical' - has highlighted a set of visions of the EU that tend to locate themselves on the neutral-to-positive side of the evaluation continuum. Yet, negative views were also observed. The EU can be seen as an instrument to counterbalance Canada's heavy dependence on the US, the regional hegemon. However, depending on the political party at the helm, this image may be utilized more or less. The EU can be seen as an organization that brought together states who are NATO members, and those are Canada's trusted partners in security domain. Yet, the EU is seen as somewhat forgetful - if not ignorant - about Canada's role and presence in the Atlantic, the EU's strategic security region. When seen through a prism of EU27 - an international organization who continues to support multilateral principles dare to Canada - the EU is seen in a positive light, as an actor who shares with Canada common values in the global outlook.

The EU perceptions from the EU-focused vantage point are dominated by negativity on mid-and short-term historical distances. While the valence remains, the focus of domesticity of it has shifted. The mid-term negativity was linked to the EU's actions in the trading area that were perceived to disadvantage Canada. The short-term negativity is linked to the internal crises of the EU that are seen to hurt the EU. While the domestic focus for negativity is now different, the dominance of the negative tenor over the years is of concern. Specifically, this is so in the context of the Canada's image of the EU as an actor who demonstrated 'neglect', 'low awareness' and event 'forgetfulness' when it comes to Canada in the transatlantic relations noted by many scholars who studied EU perceptions in Canada. 
The short-term observations in the EU-focused plane also demonstrated that there is a variation in EU perceptions across the cohorts. Public opinion on the EU is more positive vis-à-vis more negative media framing of the EU and ambivalent views among elites. This evaluation pattern invites future research to factor the cohort differences. Analysis of images of the EU in the EU-focused plane also invites to study framing of the EU across Canadian media, factoring their different political perspectives. This is in addition to the call to study perceptions of the EU across Canada's political continuum.

The world-focused images of the EU are characterized by a positive modality linked to the 'middle power' self-vision of Canada and the image of critical importance of the multilateralism for Canada to succeed globally. As a champion and vocal advocate of the rules-based global order, the EU is perceived as a kindred partner by the Canadian elites and a desirable leader by the Canadian public. This positive tenor is important for the EU27 post-Brexit - Canada's self-vision will resonate with the strategic vision of the EU and make Canada a natural key partner for the EU on the global scale. The field of perceptions studies in Canada will benefit from the next wave of research when Brexit is finalized and the US completes its next elections in 2024.

\section{References}

Adams, Michael (2003) Fire and Ice: The US, Canada and the Myth of Converging Values, Toronto: Penguin Press.

Bendiek, Annegret, Geogios, Milena, Nock, Philip, Schenuit, Felix, von Daniels Laura (2018) "EU-Canada Relations on the Rise: Mutual Interests in Security, Trade, and Climate Change", German Institute for International and Security Affairs, Research Division EU/Europe, Working Paper No. 3.

Bendiek, Annegret and Schenuit, Felix (2019) "Alliance for multilateralism: EUCanada strategic partnership”, Australian and New Zealand Journal of European Studies 11(3).

Bernard-Meunier, Marie (2006) "Did you say Europe? How Canada ignored Europe and why that is wrong”, in Cooper, Andrew F. and Rowlands, Dane (Eds.) Canada among Nations 2006. Ottawa and Waterloo: Carleton University and Centre of International Governance Innovation.

Braudel, Fernan (1989) On History. Chicago: University of Chicago Press.

Chaban, Natalia and Chaban, Anatoliy (2018) "Communicating Europe beyond its borders: imagining the EU in Ukraine post-Maidan”. European Foreign Affairs Review, 23(1/1): 119-138.

Chaban, Natalia and Knodt, Michèle (2020) "Perceptions of the EU in Ukraine after "Brexit" Referendum: Images of Capabilities and Opportunities", in Chaban, Natalia, Niemann, Arne, and Speyer, Johanna (Eds.) Changing perceptions of the EU at times of Brexit: Global Perspectives, Routledge, forthcoming.

Chaban, Natalia, Kelly, Serena and Rayroux, Antoine (2018) "Communicating the EU Externally: Media Framing of the EU's Irregular Migration Crisis (Case Studies of New Zealand and Canada)", in Bengtsson, Rikard and Sundström, Malena (Eds.) The EU and the Emerging Global Order: Essays in Honour of Ole Elgström, Lund: Lund University, 197-221. 
Chaban, Natalia, Knodt, Michèle, Headley, James (2018) "Introduction: The EU and Its Eastern Neighbours-Perceptions and Strategic Dialogue in the Region.", European Foreign Affairs Review, 23(1/1): 1-22.

Chaban, Natalia and Magdalina, Anna-Maria (2014) "External perceptions of the EU during the Eurozone Sovereign Debt Crisis", European Foreign Affairs Review, 19(2): 195-220.

Chaban, Natalia and O'Loughlin, Ben (2018) “The EU's Crisis Diplomacy in Ukraine: The Matrix of Possibilities", Journal of International Affairs, 71 (1.5)

https://jia.sipa.columbia.edu/eus-crisis-diplomacy-ukraine-matrix-possibilities [accessed 20 January 2020].

Chaban, Natalia and Zhabotynska, Svitlana (2018) "Political Images and Perceptions at the Interdisciplinary Crossroads", Cognition, Communication, Discourse, 17: 1323 .

Cooper, Andrew F., Richard A. Higgott, and Kim Richard Nossal (1993) Relocating Middle Powers: Australia and Canada in a Changing World Order, Vancouver: UBC Press.

Croci, Osvaldo and Tossutti, Livianna (2007a) "That Elusive Object of Desire: Canadian Perceptions of the European Union". European Foreign Affairs Review 12(3): $287-310$.

Croci, Osvaldo and Tossutti, Livianna (2007b) "The External Image of the European Union: Report from Canada”, in Lucarelli, Sonia (ed.) The external image of the European Union, GARNET working paper No 17/07.

Didelon-Loiseau, Clarisse and Grasland, Claude (2014) "Internal and External Perceptions of Europe/the EU in the World through Mental Maps", in Chaban, Natalia and Holland, Martin (Eds.), Communicating Europe in the Times of Crisis: External Perceptions of the European Union, London: Palgrave Macmillan, 64-95.

European Commission (2017) "Flash Eurobarometer 450: Future of Europe - Views from Outside the EU”.

European Council (2019) EU-Canada Summit joint declaration, Montreal 17-18 July 2019. https://www.consilium.europa.eu/en/press/press-releases/2019/o7/18/eucanada-summit-joint-declaration-montreal-17-18-july-2019/ [accessed: 19 January 2020].

Fisher, Glen (1997) Mindsets: The role of culture and perception in international relations, $2^{\text {nd }}$ ed. Yarmouth, Maine: Intercultural Press.

Gänzle, Stefan and Retzlaff, Steffi (2008) "So, the European Union is 50... Images of the EU and the 2007 German Presidency in Canadian News”, International Journal 63(3): 627-644.

Hawes, Michael K. (1984) Principal Power, Middle Power, or Satellite?, Toronto: York Research Programme in Strategic Studies.

Herrmann, Richard K., Voss, James F., Schooler, Tonya Y. E., and Ciarrichi, Joseph (1997) Images in international relations: an experimental test of cognitive schemata. International Studies Quarterly, 41(3): 403-433.

Horbyk, Roman (2017) Mediated Europes: discourse and power in Ukraine, Russia and Poland during Euromaidan. Published PhD dissertation, Södertön University Doctoral Dissertations. 
Hurrelmann, Achim (2018) "External Perceptions of the EU in Canada", paper presented at the workshop External Perceptions of the EU after Brexit and their Impact on Foreign Policy, supported by the Thyssen Foundation, UACES, Erasmus+ Jean Monnet Programme and the University of Mainz, 28-29 June, University of Mainz, Germany.

Hurrelmann, Achim (2020) “Canada's Two Europes: Brexit and the Prospect of Competing Transatlantic Relationships", in Chaban, Natalia, Niemann, Arne, and Speyer, Johanna (Eds.) Changing perceptions of the EU at times of Brexit: Global Perspectives, Routledge, forthcoming.

Ipsos Mori (2016) "Reactions to Brexit across 16 Countries”. August 3. 2019. https://www.ipsos.com/ipsos-mori/en-uk/reactions-brexit-across-16-countries [accessed: 21 May 2019].

Jones, David and Kilgour, David (2007) Uneasy Neighbo(u)rs: Canada, the USA and the Dynamics of State, Industry and Culture, Mississauga: John Wiley and Sons.

Knodt, Michèle and Chaban, Natalia (2019) "New Opportunities for the EU-Canada Strategic Partnership", Australian and New Zealand Journal of European Studies, 11(3).

Leuprecht, Christian and Hamilton, Rhianna (2019) "New opportunities in Common Security and Defence Policy: Joining PESCO”, Australian and New Zealand Journal of European Studies, 11(3).

Movahedi, Siamak (1985) "The social psychology and the politics of international images", Human affairs, 8: 1-11.

Nossal, Kim R. (2010) “'Middlepowerhood' and 'Middlepowermanship' in Canadian Foreign Policy”, in Hynek, Nik and Bosold, David (Eds.), Canada's Foreign and Security Policy: Soft and Hard Strategies of a Middle Power, Toronto: University of Toronto Press: 20-34.

PPMI/NCRE/ NFG (2015) Analysis of the perceptions of the EU and the EU's policies abroad. Commissioned by European External Action Service (EEAS).

http://ec.europa.eu/dgs/fpi/documents/showcases/eu perceptions study executive summary with_country fiches.pdf [accessed: 05 August 2016].

Rabson, Mia (2018) “Scheer backs Brexit despite chaos, says it's giving Britain back control of itself", The Canadian Press, November 16, https://www.cbc.ca/news/politics/scheer-brexit-support-1.4908420 [accessed: 5 January 2020].

Rayroux, Antoine (2018) “The EU's Reputation in Canada: Still a Shallow Strategic Partnership?", in Chaban, Natalia and Holland, Martin (Eds.), Communicating Europe in the Times of Crisis: External Perceptions of the European Union, London: Palgrave Macmillan, 64-95.

Rayroux, Antoine (2019) "Threats to multilateralism and the future of the EU-Canada Strategic Partnership: A view from Canada”, Australian and New Zealand Journal of European Studies, 11(3)

Retzlaff, Steffi and Gänzle, Stefan (2008) "Constructing European Union in Canadian news”, Critical Approaches to Discourse Analysis across Disciplines, 2(2): 67-89. 
Scheer, Andrew (2016) “A strong Britain is an independent Britain. It's difficult not to see the case for leaving the EU”. National Post, 20 June.

https://nationalpost.com/opinion/andrew-scheer-a-strong-britain-is-anindependent-britain [accessed: 5 January 2020].

Tsuruoka, Michito (2006) "How External Perspectives of the European Union are Shaped: Endogenous and Exogenous Sources", paper prepared for the 2oth World Congress of the International Political Science Association (IPSA), Fukuoka, Japan, 9-13 July 2006, 'EU-Asia Relations and Security Matters' (RCO3 on European Unification).

Verdun, Amy (2019) “EU-Canada Strategic Partnership: Ups and Downs”, Australian and New Zealand Journal of European Studies, 11(3).

Wintour, Patrick and Mason, Rowena (2019) "Trump cuts short Nato summit after fellow leaders' hot-mic video", The Guardian, December 4, https://www.theguardian.com/us-news/2019/dec/o4/trump-describes-trudeau-astwo-faced-over-nato-hot-mic-video [accessed: 7 December 2019].

Woods, Donna E. and Verdun, Amy (2010) "Canada and the European Union: A Review of the Literature from 1982 to 2010", International Journal, 66(1): 9-21.

Zyla, Benjamin (2019) "Middle-power internationalism In-between European 'Paradise' and American 'Power'? Canada's political role in an age of Trumpism and Brexit”, Australian and New Zealand Journal of European Studies, 11(3). 